Vol. 9 (2000): 259-268.

\title{
Equilibrium moisture content of flax/linseed and fibre hemp straw fractions
}

\author{
Hanna-Riitta Kymäläinen and Antti Pasila \\ Department of Agricultural Engineering and Household Technology, PO Box 27 (Viikki F), FIN-00014 \\ University of Helsinki, Finland, e-mail: hanna-riitta.kymalainen@helsinki.fi
}

\begin{abstract}
This preliminary study of the equilibrium moisture content (EMC) of bast fibre plants (Linum usitatissimum L. and Cannabis sativa L.) examines three fractions, fibre, fine shive and coarse shive. The plants were harvested at two times, the first in autumn and the second in spring. The autumn harvest yielded unretted, green material, while the frost-retted material harvested in spring may be classified as overretted. Interesting differences in EMC were found in the dampest air between the two harvest times irrespective of plant species: green fractions were faster to mould at the beginning and lost more weight in the 2-week test period than did the frost-retted samples. The green samples also attained higher EMCs before beginning to mould.
\end{abstract}

Key words: fibre plants, fibres, separation, humidity, wetting, equilibrium moisture content, Linum usitatissimum, Cannabis sativa

\section{Introduction}

Traditionally bast fibre plants have been cultivated for seeds or long spinning fibres. Only these, the most valuable parts have been used, and typically only one of them at a time. Recent changes in Finnish agriculture have prompted farmers to look for new approaches enabling the old cultivation plants to be applied in new ways. The cost factor and introduction of new application areas have led to a demand for total exploitation of the bast fibre plants, which in turn requires new fractioning techniques and knowl- edge of the behaviour of the fractions (Pehkonen et al. 2000).

In the North, where there is a huge variation between outdoor temperature and the relative humidity of air during the year, the moisture content of the stems or of the raw material produced from the plants is one of the most critical factors in achieving materials of an acceptable quality. The moisture content of the raw material is therefore of special importance, as it is one of the properties that determine the selection of the raw material for a specific end-use product. The other important factor in moisture behaviour lies in the harvest, storage and processing chain be- 


\section{AGRICULTURAL AND FOOD SCIENCE IN FINLAND}

\section{Kymäläinen, H.-R. \& Pasila, A. EMC of Linum usitatissimum and Cannabis sativa fractions}

fore the production of raw material. This production chain includes several phases and delay periods during which the material may be subjected to fluctuating conditions. Before the desired processed fraction is achieved, the straw or processed straw will have several opportunities to alter its properties due to humidity.

Equilibrium humidity is understood as a hygroscopic equilibrium humidity, that is, the amount of water a material binds from the air at a certain temperature and relative humidity $(\mathrm{RH})$ (Leppävuori et al. 1991). If a dry material is submitted to a constant temperature and $\mathrm{RH}$, then an equilibrium, a balance, will form between the humidity of the material and that of its surroundings. An adsorption/desorption curve with several equilibriums at different relative air humidities is called a (ad/de)sorption isotherm (Nevander and Elmarsson 1994). If products are subjected to fluctuating atmospheric conditions, the equilibrium moisture content (EMC) changes constantly (Skaar 1988).

According to Skaar (1988), EMC has two phases:

1. monolayer sorption: the attraction between the sorbent (vapour) and sorbate is greater than that between the sorbent molecules themselves in the liquid state;

2. multilayer sorption: the attraction of the sorbed molecules to the sorbate is minimal.

In addition, Nevander and Elmarsson (1994) have described a third phase, in which the humidity in the material is high, and menisci begin to form. This leads to the domination of capillary condensation. The EMC curve rises steeply. In the last period the practical difficulty arises of measuring the equilibrium in the last few per cent up to $100 \% \mathrm{RH}$. The last period is nevertheless very important.

Equilibrium humidity has been found to have importance in the food, textile, and wood sectors. Moisture content may be expressed on a dry basis (d.b.) or a wet basis (w.b.), depending on the context in which the term is used.

In food products, the systems' equilibrium relative humidity is said to be closely related to the chemical, physical and biological properties of the products, and hence to their quality and stability, which in turn affect packaging practices and storage conditions (Rockland and Stewart 1978). In this respect, the term water activity is also often used. Water activity refers to the availability of water in a food medium, and there is a direct correlation between microbial growth on a substrate and the thermodynamic water activity of the substrate (Scott 1953).

In textiles, moisture also has several other effects, for example:

- the more hydrophilic a material, the easier dyeing and other processes in acqueous solutions will be

- a very hydrophilic material is slow to dry

- dimensional and tensile properties are dependent on moisture content (Needles 1986).

Moisture regains (d.b.) are usually determined for textile fibres in air at $21 \pm 1^{\circ} \mathrm{C}$ and $65 \%$ $\mathrm{RH}$ (Needles 1986). The moisture regain for flax and hemp fibre is $12 \%$, and for cotton, which is very nearly pure cellulose, 7-9\% (Mauersberger 1948). For example, in textile laundering the moisture content is expressed on w.b. For cotton a $25-30 \%$ moisture absorbency (w.b.) has been measured at $100 \%$ RH of air (Needles 1986).

Also for wood, moisture content is usually expressed on d.b. (Skaar 1988). The EMC behaviour of flax/linseed and hemp shive containing 23-30\% of lignin (Sharma 1992, Koslowski et al. 1997) may be closer to that of wood than of fibre, because a woody cell wall has a lignin content of 20-35\% (Siau 1995). When wood adsorbs water, the cell walls swell until they become water-saturated. This moisture content is called the wood's fibre saturation point (Parham and Gray 1984). According to Kirk and Cowling (1984), wood will not decay as long as it is kept below its fibre saturation point, which is $\sim 27 \%$ of its dry weight.

It has been noticed in practice that humidity affects the stability of bast plants and fractions. Food consists of biological matter which, however, differs from that of non-food fibrous ma- 
Vol. 9 (2000): 259-268.

terials. Therefore it is essential to examine the stability of bast fibre plants from the practical point of view of the production chain. EMC also plays a role in the ease with which stems are processed in and after harvest (Pasila et al. 1998). The higher the equilibrium humidity, the higher is the friction coefficient between the stem and processing equipment and thus the more difficult the stems are to process. This has a marked effect on the operation of the equipment, especially in humid circumstances.

The present study sought to provide insight into the adsorption EMCs of fractioned flax, linseed and hemp straw at two harvesting times, the first in autumn (green straw) and the second in spring (overretted straw).

\section{Material and methods}

\section{Plants and harvesting time}

In this study two plants, flax (Linum usitatissimum L.) and hemp (Cannbis sativa L.) were investigated. Two types of Linum usitatissimum were used: flax (varieties Viola and Viking) and linseed (variety Helmi). The hemp varieties were Felina 34 and Kompolti hybrid. Below, the terms flax, linseed and hemp are used. The plant samples were picked at various farms in southern Finland in 1997. The plants were cultivated according to common farming practices in Finland (Hakala and Hongisto 1994), and were harvested in autumn when the straw was still green and in spring using the dry-line method (Pasila 1999). The focus here is on both the green (unretted) and frost-retted (overretted) straw of each of the three plant types. Harvested plants were mechanically separated into three fractions: fibre, coarse shive and fine shive. Detailed information on the plants, separation process and basic properties of the fractions is presented by Kymäläinen et al. (unpublished). Approximately $1-5 \mathrm{~kg}$ amount of straw yielded fractions of the size of $0.08-1 \mathrm{~kg}$.

\section{EMC determination}

The experiment was conducted with a completely random design. Three randomly picked replicate samples from each treatment were tested for equilibrium humidity. All samples were divided into six parcels, one parcel containing 12 randomly chosen samples, and one parcel being investigated at a time. One sample consisted of 1$1.5 \mathrm{~g}$ of room-dry fibre or 2.5-3 g of room-dry shive. The sample was weighed into a weighed metal bowl (height $25 \mathrm{~mm}$, diameter of bottom $45 \mathrm{~mm}$ and diameter of top $60 \mathrm{~mm}$ ) without specific density equalization. An analytical balance was used for weighing. The moisture content of the room-dry material was measured on a separate sample taken at the same time.

Twelve metal sample bowls (holding samples) were put in a plastic container placed in a conditioning room $\left(\mathrm{t}=20 \pm 2^{\circ} \mathrm{C}, \mathrm{RH}=65 \pm 2 \%\right)$. In the conditioning ISO 139 (1973) was followed without pre-conditioning. The operating principle of the equipment is shown in Figure 1. The relative humidity of the air in the test containers was $15 \%, 76 \%$ and $97 \%$, respectively. These points were selected to reflect the shape of a typical EMC curve, which is relatively flat at intermediate values of relative humidities of air, but has a gradually steeper slope towards high values of RH. The highest RHs of air are interesting due to the possible moulding of the biological matter typical in those conditions. The temperature was $20 \pm 1^{\circ} \mathrm{C}$. The same samples were put under different conditions to achieve equilibrium humidity in the order $15 \%$ (RH of air) $\rightarrow 76 \% \rightarrow 97 \%$, which were obtained using the following salts or water, respectively (NT BUILD 130, 1990): LiCl (salt + saturated salt liquid), $\mathrm{NaCl}$ (salt + saturated salt liquid), and $\mathrm{H}_{2} \mathrm{O}$ (distilled water). The humidity and temperature of the container were measured with a Rotronic Hygromer HP 100A probe.

A set of 12 samples was kept under the chosen conditions until each of them reached the EMC. Samples were weighed once a day in the conditioning room. For weighing the sample 


\section{Kymäläinen, H.-R. \& Pasila, A. EMC of Linum usitatissimum and Cannabis sativa fractions}

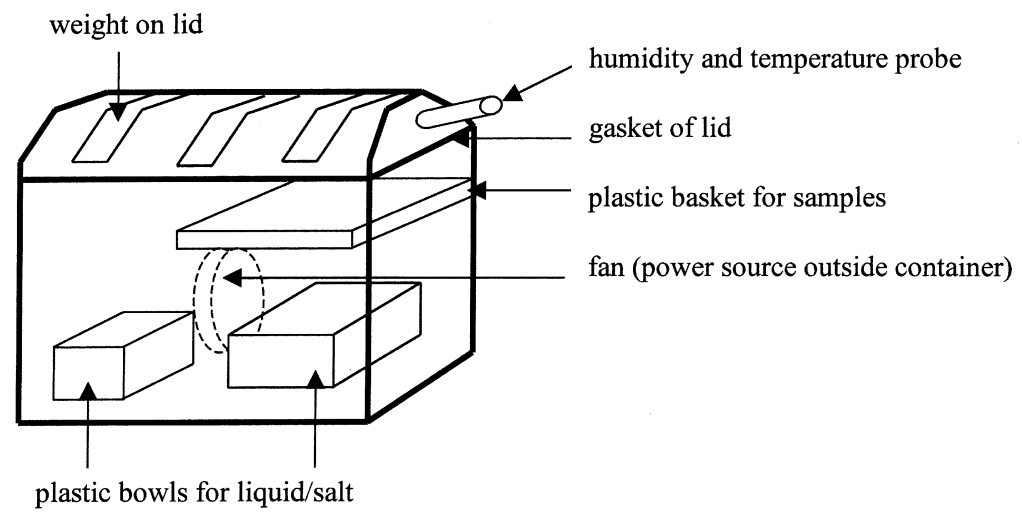

Fig. 1. Equipment used in the Equilibrium moisture content measurement. basket was lifted out of the container and covered with a lid.

Interesting differences between harvest times were observed, and therefore the data were submitted to analysis of variance with a single criterion of classification (Steel and Torrie 1980) to test the difference in the EMCs and beginning of mass loss between green (harvested in autumn) and frost-retted samples (harvested in spring). Each plant was tested separately using harvest time (autumn/spring) as a criterion of classification. A significance level of 0.05 was used.

\section{Results}

At $15 \%$ and $76 \%$ RH of air, the EMC values of the green and frost-retted fractions were close to each other when one fraction was looked at a time (Fig. 2). EMC results calculated on d.b. are presented in Table 1. The most interesting differences in the EMC values were found in the dampest air: at $97 \% \mathrm{RH}$ of air all unretted samples had clearly higher EMCs than had the frostretted ones. Also in the variance analysis, P-values were low (maximally 0.007) in the dampest air; at $15 \% \mathrm{RH}$ of air the $\mathrm{P}$-values were as high as 0.949 (Table 2). P-values at $15 \%$ and $76 \%$ $\mathrm{RH}$ of air were in almost all cases clearly higher than they were in the dampest air.
Due to the small number of measurement points, sorption isotherms were not drawn. However, the present points were found to be consistent with the shape of the sorption isotherm curve of for example wood (Skaar 1988, Nevander and Elmarsson 1994).

The three examined plants behaved similarly. At some cases one plant seemed to differ from the other two, for example all frost-retted hemp fine shive samples had the highest EMC values at $97 \%$ RH of air (Fig. 2). However, statistical deviations on the whole do not give right to interpret real differences between the plants.

In the dampest air, nearly all the samples began to lose weight due to moulding. The EMC values in the dampest air (97\% RH) are in fact the highest moisture contents that the samples reached before losing weight (Fig. 2). Frost-retted samples were on average, a little slower at starting to mould (Fig. 3), but the variation between the three replicates was considerable, from 0 (green linseed fibre, green hemp fine shive, green coarse shive samples) to 6 days (frost-retted linseed fine shive). Variance analysis showed the biggest differences for flax and linseed at the beginning of moulding: The P-values between unretted and frost-retted samples for flax were 0.015 (fibre), 0.049 (fine shive), and $<0.000$ (coarse shive); for linseed 0.038, 0.065 and $<0.000$ (respectively), and for hemp 0.065, 0.184 and 0.238 . The unretted samples attained higher EMCs before losing weight than did the frostretted samples (Fig. 2). 
Vol. 9 (2000): 259-268.
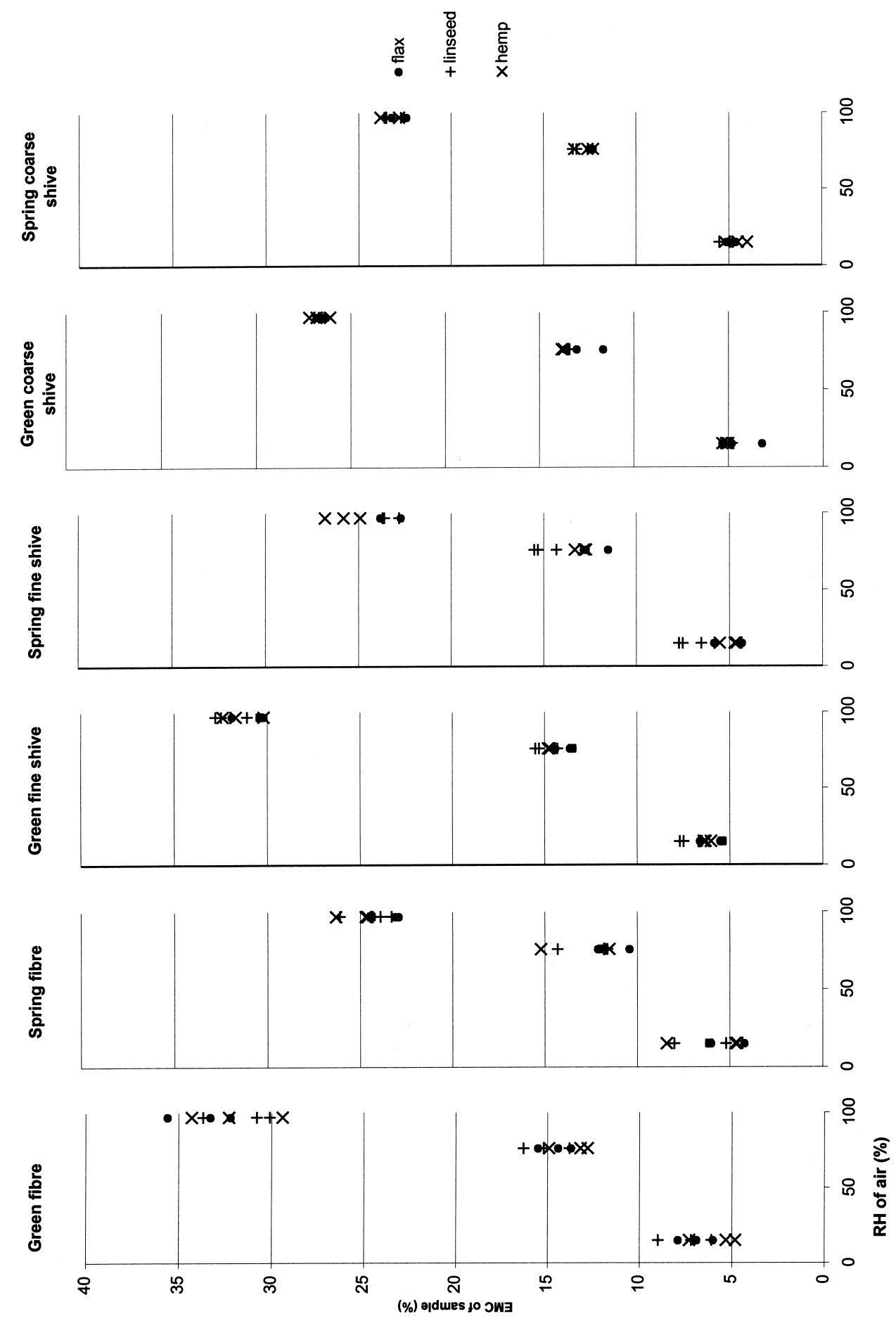

Fig. 2. Water sorption Equilibrium moisture content (EMC) of fibre, fine shive and coarse shive (three replicates). $\mathrm{RH}=$ relative humidity. 


\section{Kymäläinen, H.-R. \& Pasila, A. EMC of Linum usitatissimum and Cannabis sativa fractions}

Table 1. Equilibrium moisture contents of samples, dry basis (equals moisture regains).

\begin{tabular}{|c|c|c|c|c|c|c|c|}
\hline \multirow[t]{3}{*}{ sample } & \multirow[t]{3}{*}{ replicate } & \multicolumn{6}{|c|}{ moisture content \% (d.b.) } \\
\hline & & \multicolumn{3}{|c|}{ At $76 \% \mathrm{RH}$ of air } & \multicolumn{3}{|c|}{ at $97 \% \mathrm{RH}$ of air } \\
\hline & & fibre & fine shive & coarse shive & fibre & fine shive & coarse shive \\
\hline green & 1 & 26.6 & 16.8 & 15.0 & 36.2 & 46.7 & 36.2 \\
\hline \multirow{2}{*}{ flax } & 2 & 18.3 & 15.6 & 15.7 & 26.0 & 43.6 & 26.0 \\
\hline & 3 & 15.8 & 15.8 & 13.2 & 35.6 & 43.3 & 35.6 \\
\hline green & 1 & 25.2 & 18.3 & 15.6 & 36.7 & 49.2 & 36.7 \\
\hline \multirow[t]{2}{*}{ linseed } & 2 & 17.9 & 16.7 & 15.5 & 35.9 & 44.2 & 35.9 \\
\hline & 3 & 19.4 & 18.0 & 15.6 & 36.2 & 48.2 & 36.2 \\
\hline green & 1 & 17.5 & 17.4 & 16.0 & 27.4 & 50.4 & 27.4 \\
\hline \multirow[t]{2}{*}{ hemp } & 2 & 14.7 & 17.2 & 15.9 & 36.7 & 43.2 & 36.7 \\
\hline & 3 & 15.2 & 17.4 & 15.8 & 35.3 & 46.4 & 35.3 \\
\hline spring & 1 & 13.8 & 13.0 & 14.0 & 28.9 & 29.3 & 28.9 \\
\hline \multirow[t]{2}{*}{ flax } & 2 & 11.6 & 14.6 & 14.2 & 30.2 & 31.3 & 30.2 \\
\hline & 3 & 13.5 & 14.6 & 14.3 & 30.3 & 31.3 & 30.3 \\
\hline spring & 1 & 13.1 & 14.5 & 15.2 & 29.4 & 29.5 & 29.4 \\
\hline \multirow[t]{2}{*}{ linseed } & 2 & 13.2 & 14.6 & 15.5 & 30.8 & 30.9 & 30.8 \\
\hline & 3 & 16.7 & 14.7 & 15.5 & 30.7 & 31.1 & 30.7 \\
\hline spring & 1 & 19.6 & 14.6 & 15.3 & 32.0 & 35.5 & 32.0 \\
\hline \multirow[t]{2}{*}{ hemp } & 2 & 20.4 & 14.6 & 14.0 & 29.5 & 33.2 & 29.5 \\
\hline & 3 & 18.0 & 15.4 & 14.4 & 31.4 & 34.7 & 31.4 \\
\hline
\end{tabular}

$\mathrm{RH}=$ relative humidity

Table 2. Differences between Equilibrium moisture contents (EMC) of green and frost-retted samples. Difference, calculated from means of three replicates $=\left(\left(\mathrm{EMC}_{\text {green }}-\mathrm{EMC}_{\text {frost }}\right) / \mathrm{EMC}_{\text {green }}\right) * 100 \%$.

\begin{tabular}{|c|c|c|c|c|c|c|c|}
\hline \multirow[t]{2}{*}{ Plant } & \multirow[t]{2}{*}{ Fraction } & \multicolumn{2}{|c|}{$15 \% \mathrm{RH}$ of air } & \multicolumn{2}{|c|}{$76 \% \mathrm{RH}$ of air } & \multicolumn{2}{|c|}{$97 \% \mathrm{RH}$ of air } \\
\hline & & $\begin{array}{c}\text { Difference } \\
\%\end{array}$ & P-value & $\begin{array}{c}\text { Difference } \\
\%\end{array}$ & P-value & $\begin{array}{c}\text { Difference } \\
\%\end{array}$ & P-value \\
\hline flax & fibre & 21.6 & 0.144 & 21.1 & 0.015 & 30.4 & 0.001 \\
\hline linseed & $"$ & 17.5 & 0.360 & 17.0 & 0.088 & 22.5 & 0.007 \\
\hline hemp & $"$ & -1.7 & 0.949 & 6.6 & 0.553 & 21.3 & 0.011 \\
\hline flax & fine shive & 9.1 & 0.445 & 10.8 & 0.041 & 24.0 & $<0.001$ \\
\hline linseed & $"$ & 29.0 & 0.007 & 15.0 & 0.004 & 27.3 & $<0.001$ \\
\hline hemp & $"$ & 20.9 & 0.014 & 12.4 & 0.001 & 17.8 & 0.003 \\
\hline flax & coarse shive & -10.5 & 0.513 & 2.6 & 0.605 & 13.5 & $<0.001$ \\
\hline linseed & $"$ & -6.8 & 0.252 & 1.0 & 0.148 & 12.4 & $<0.001$ \\
\hline hemp & $"$ & 11.0 & 0.190 & 7.3 & 0.028 & 12.1 & 0.002 \\
\hline
\end{tabular}

$\mathrm{RH}=$ relative humidity

Mass loss during the 14 day research period depended on the speed with which the fractions began to lose weight: the sooner a sample began to lose its mass, the bigger was the mass loss at the end of the test period (Fig. 4). 


\section{AGRICULTURAL AND FOOD SCIENCE IN FINLAND}

Vol. 9 (2000): 259-268.

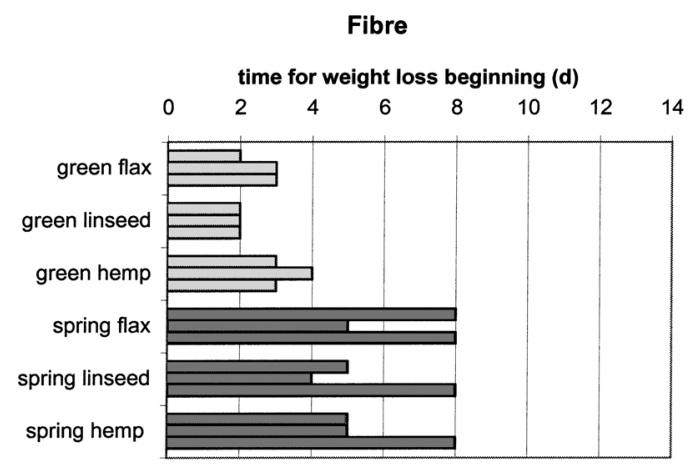

\section{Fine shive}

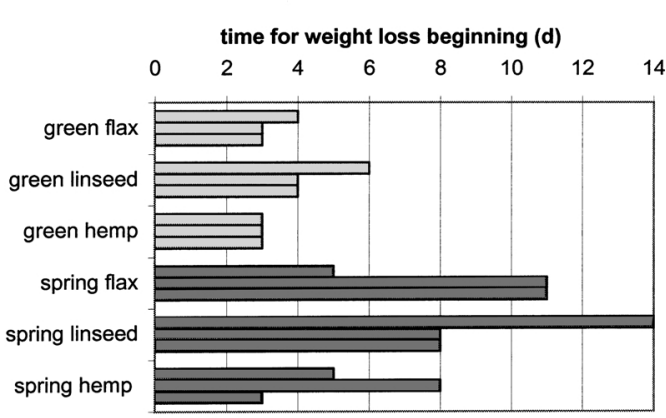

Coarse shive

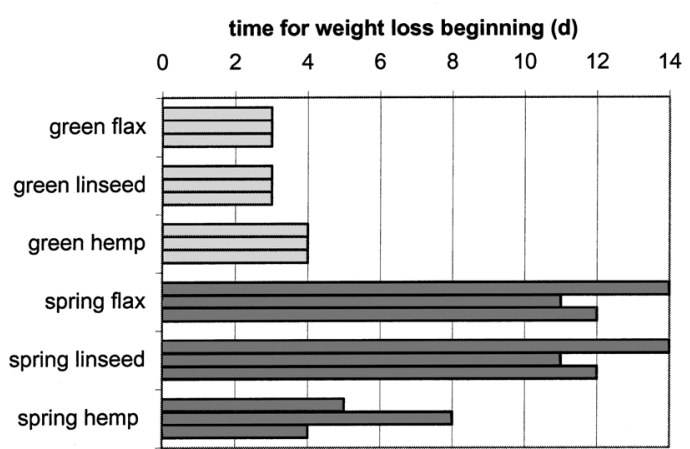

Fig. 3. Time (d) during which samples began to lose weight at $>95 \%$ relative humidity due to moulding (three replicates).

\section{Discussion}

Clear differences were found between all green and frost-retted fractions at the highest $\mathrm{RH}$ of

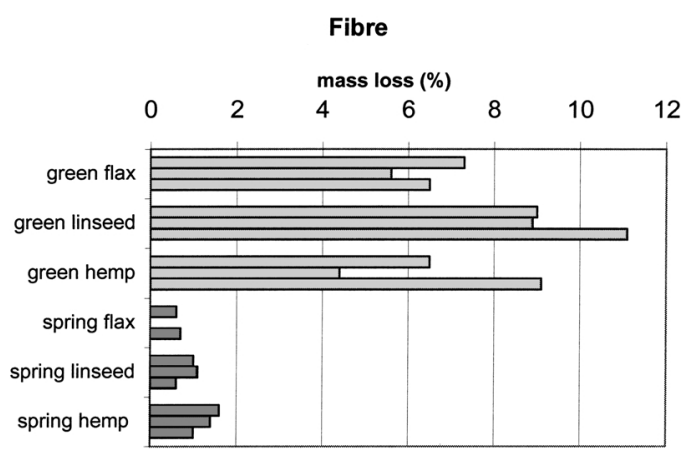

Fine shive

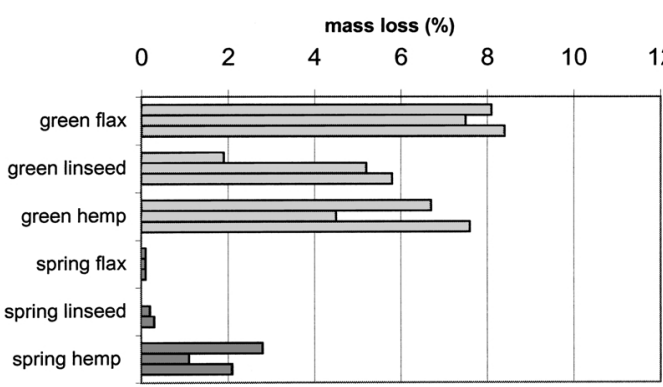

Coarse shive

mass loss $(\%)$
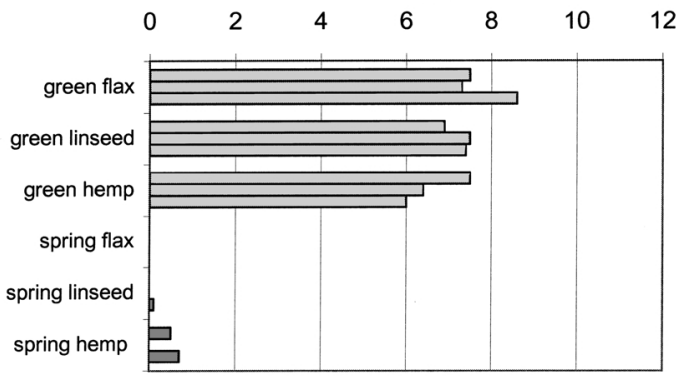

Fig. 4. Mass loss of samples during 2-week research period (three replicates).

air, which was found to be the most interesting condition. When the results of EMC and capillarity studies (Kymäläinen et al. unpublished) were compared, differences were noted in the behaviour of the samples. In the capillary test, a tube filled with the fraction to be investigated was brought into direct contact with water. Water was then sucked into the material by capillary forces. The frost-retted hemp fibres showed 


\section{AGRICULTURAL AND FOOD SCIENCE IN FINLAND}

\section{Kymäläinen, H.-R. \& Pasila, A. EMC of Linum usitatissimum and Cannabis sativa fractions}

good capillarity; frost-retted flax and linseed the poorest. In the dampest air of the EMC test, all frost-retted samples behaved similarly, differing from the unretted samples, and irrespective of the plant species. The direct water intake differs from one plant species to another, but also the moistening or water contact type affects the ability of the fractions to absorb moisture.

Moisture behaviour is related to the chemical and morphological structure of plants. Pectins and hemicellulose absorb more moisture from the air than does cellulose (Focher et al. 1992). The amount of pectin decreases in fibre during retting, and thus frost-retted fibres were expected to absorb less water than unretted ones, which was also observed in the dampest air as lower moisture contents before moulding. On the other hand, lignin, which contains few free hydroxyls and is thus less hydrophilic than cellulose or hemicellulose (Parham and Gray 1984), may have lowered the hygroscopicity of unretted fibres due to the higher shive content of those fibres (Kymäläinen et al. unpublished).

Coarse shive could be expected to behave more like woody material than fine shive due to the other plant components of fine shive. Unretted and retted coarse shive samples showed conformity in the capillarity test (Kymäläinen et al. unpublished), which can be explained by the similar compositions of unretted and retted shive (Akin et al. 1996). This explanation does not hold for the EMC test at $97 \% \mathrm{RH}$, because a difference of about 5 percentage units was noticed in those EMCs of green and frost-retted shive irrespective of plant species. The manner in which water passes into a fraction in direct water contact differs from moisture uptake from air, a fact of importance in the production chain and for the usage of products made of flax, linseed or hemp straw.

Almost all dry weight moisture contents of samples at the highest RH of air exceed the fibre saturation point of wood, $27 \%$ (Table 1), and therefore it is not surprising that they began to decay (Kirk and Cowling 1984). In 76\% RH of air, the dry weight moisture contents varied from $11.6 \%$ to $26.6 \%$ (Table 1 ), and no degradation occurred. Lignin is known to inhibit microbial degradation of plants (Akin 1989). Comparison of lignin-poor fibre and lignin-rich shive did not show any such inhibition here: The biggest differences in microbial degradation were found in green fractions, both fibre and shive, compared to frost-retted fractions.

The research problem of this study arose from a national interest of getting advantage of the retting and drying process in winter and spring. This study is related to a harvest technology research focusing on the frost-retting, and therefore no dew-retting or enzymatic retting was used. In Finland it is important to find alternatives for traditional retting procedures because of the high drying costs. In the future it would be valuable to compare the green and frost-retted material with dew-retted straw, which is widely used in Europe.

The present research was introductory in setting from the instrumentation point of view. If a greater range of $\mathrm{RH}$ conditions were used, a water sorption isotherm might be figured. The number of replicates was restricted by the experimental procedure. The large number of samples in a parcel increased the variation due to changes in the sample masses during weighing under $\mathrm{RH}$ conditions different from those in the container. The effect of this on the EMC results at the two highest humidities of air was calculated to be some decimals of percentage units, which constitutes only a minor part of the total variation. Despite these weaknesses, we conclude, that the fractions examined differed clearly between the two retting degrees (harvest times). The aim of the research was thus achieved, and further studies may be continued from the information acquired.

Acknowledgements. We thank the Academy of Finland, the Technology Research Center of Finland, and the Finnish Cultural Foundation, for financial support for this study. 
Vol. 9 (2000): 259-268.

\section{References}

Akin, D.E. 1989. Histological and physical factors affecting digestibility of forages. Agronomy Journal 81: 17-25.

- , Gamble, G.R., Morrison, W.H. III \& Rigsby, L.L. 1996. Chemical and structural analysis of fibre and core tissues from flax. Journal of the Science of Food and Agriculture 72: 155-165.

Focher, B., Marzetti, A. \& Sharma, H.S.S. 1992. Changes in the structure and properties of flax fibre during processing. In: Sharma, H.S.S. \& Sumere, C.F. van (eds.). The Biology and Processing of Flax. Belfast: M Publications. p. 329-342.

Hakala, N. \& Hongisto, S. (eds.). 1994. Öljypellavan viljelyopas. Savonlinna: Elixi Oil Oy. 15 p.

ISO 139, 1973 (EN 20139:1992). Textiles - Standard atmospheres for conditioning and testing.

Kirk, T.K. \& Cowling, E.B. 1984. Biological degradation of solid wood. In: Rowell, R. (ed.). The chemistry of solid wood. Advances in Chemistry Series 207. Washington DC: American Chemical Society. p. 455-487.

Koslowski, R., Mieleniak, B. \& Przepiera, A. 1997. Particleboards and insulating board on base hemp shives and hemp straw. Proceedings of the Flax and other Bast Plants Symposium, Poznan, Poland, 30 September - 1 October. p. 92-100.

Kymäläinen, H.-R., Hautala, M., Kuisma, R. \& Pasila, A. 2000. Capillarity of flax/linseed (Linum usitatissimum L.) and fibre hemp (Cannabis sativa L.) straw fractions. Industrial Crops and Products 00: 000-000.

Leppävuori, E., Kanerva, P., Vähäkallio, P. \& Prokki, H. 1991. Rakennusaineet. Helsinki: Otatieto 453. $346 \mathrm{p}$.

Mauersberger, H.R. (ed.). 1948. Matthews' Textile Fibers. USA: John Wiley \& Sons. 1133 p.

Needles, H.L. 1986. Textile Fibers, Dyes, Finishes, and Processes. USA: Noyes Publications. 227 p.

Nevander, L.E. \& Elmarsson, B. 1994. Fukthandbok, praktik och teori. Stockholm: Svensk Byggtjänst och författarna. $538 \mathrm{p}$.

NT BUILD 130 1990. Building materials: water vapour transfer rate, permeance and diffusion resistance. Nordtest. Ed. 2, appr. 1990-08.

Parham, R.A. \& Gray, R.L. 1984. Formation and structure of wood. In: Rowell, R. (ed.). The chemistry of solid wood. Advances in Chemistry Series 207. Washington DC: American Chemical Society. p. 3-56.

Pasila, A. 1999. The effect of frost on fibre plants and their processing. Fifth International Conference on Frontiers of Polymers and Advanced Materials, 2125 June 1999, Book of Abstracts, Poznan, Poland. p. 40-41.

- , Pehkonen, A., Lalli, J., Pehkonen, T. \& Sihvola, J. 1998. Kasvikuitueristeen tuotannon koneketju (Machinery in Production af Plant Based Insulation Materials). Maatalousteknologian julkaisuja 23. University of Helsinki, Department of Agricultural Engineering and Household Technology. 68 p.

Pehkonen, A., Kymäläinen, H.-R. \& Pasila, A. 2000. Nonfood -tuotannon mahdollisuudet. In: Marttila, J. \& Ahlstedt, J. (eds). Maataloustieteen päivät 2000. Talous ja teknologia. Maatalouden taloudellinen tutkimuslaitos, julkaisuja 94. Helsinki. p. 51-63.

Rockland, L.B. \& Stewart, G.F. (eds.). 1978. Properties of water in relation to food quality and stability. International Symposium on Properties of Water, $2 \mathrm{~d}$, Osaka, 1978. Academic Press, Inc. New York.

Scott, W.J. 1953. Water relations of Staphylococcus aureus at $30^{\circ} \mathrm{C}$. Australian Journal of Biological Sciences 6: $549-564$.

Sharma, H.S.S. 1992. Utilization of flax shive. In: Sharma, H.S.S. \& Sumere, C.F. van (eds.). The Biology and Processing of Flax. Belfast: M Publications. p. 537-543.

Siau, J.F. 1995. Wood: Influence of Moisture on Physical Properties. Department of Wood Science and Forest Products, Virginia Polytechnic Institute and State University. $227 \mathrm{p}$.

Skaar, C. 1988. Wood-Water Relations. Germany: Springer-Verlag. 283 p.

Steel, R.G.D. \& Torrie, J.H.1980. Principles and procedures of statistics. USA: McGraw-Hill, Inc. 633 p. 
Kymäläinen, H.-R. \& Pasila, A. EMC of Linum usitatissimum and Cannabis sativa fractions

\section{SELOSTUS}

\section{Pellavan ja kuituhampun korren jakeiden tasapainokosteus}

Hanna-Riitta Kymäläinen ja Antti Pasila

Helsingin yliopisto

Tutkimuksessa kartoitettiin jakeistetun kuitupellavan, öljypellavan ja kuituhampun tasapainokosteuskäyttäytymistä kolmessa eri ilmankosteudessa. Korret jakeistettiin mekaanisesti kuiduksi sekä hienojakoiseksi ja karkeaksi päistäreeksi. Korjuu tapahtui syksyllä ja keväällä: syksyllä saatiin liottamattomia varsia, keväällä korjatut voitiin luokitella ylilionneiksi. Mielenkiintoisimmat erot korjuuaikojen välillä havaittiin korkeimmassa ilmankosteudessa kasvilajista riippumatta: syksyllä korjatut vihreät jakeet alkoivat homehtua nopeammin ja menettivät enemmän massastaan kahden viikon tutkimusjakson aikana kuin keväällä korjatut jakeet. Vihreät jakeet saavuttivat kevätkorjattuja korkeamman kosteuspitoisuuden ennen kuin niiden massa alkoi homehtumisen vuoksi laskea. 